\title{
FALL CROW ROOSTS \\ IN RESIDENTIAL SASKATOON
}

C. STUART HOUSTON, 863 University Drive, Saskatoon, Saskatchewan, S7N 0J8.

The Common Crow began nesting along residential streets of Saskatoon about 1968.' The early nests were well hidden in large spruce trees, but in June 1978 । waiked twice each day beneath a successful nest only $8 \mathrm{~m}$ above the sidewalk in the " 900 " block of University Drive. It caused an unmistakable splash of "whitewash" on the sidewalk, and on looking directly up one could see the three young sitting on the edge of the nest. Crows have increased since 1968 and now there is at least one resident pair per city block, within a few blocks of the river. They have become one of the commonest species seen in my twice daily walk from my home to the University Hospital, half a mile distant, from early April through July.

For years, fall congregations of crows have assembled along the river south of Saskatoon, just outside the city limits. In 1977, Sandra and Tony Johns found flocks of 2,000 on 4 and 5 September at Wildwood Golf Course well away from the river on the eastern city limits, and this flock increased to 6,000 on 6 September. ${ }^{2}$

In 1978, crows were first reported flocking in residential areas of Saskatoon when Muriel Galloway sighted more than 120 at the 25th Street bridge at 21:00 on 11 August, and Pat O'Neil at 1125 Elliott Street, just two city blocks to the southeast, recorded 100 on 12 August and 70 on 13 August, decreasing to 16, 20 and 20 crows on the 14th, 19th and 20th days of the month, respectively, and only two or three each day ir September. ${ }^{3}$

In 1979, while walking home from work, I encountered much large groups of crows than ever before. Or 2 October at 18:30, I counted ove 200 crows gathered in the trees nea the University's memorial gates, jus south of the President's residence On 3 October, they were just begin ning to gather at 18:10, with 14 already roosting in the same trees and stragglers flying across the residential areas of the city to joir them. On 4 October, there was already a noisy flock in the trees a $18: 28$, while 46 more came from the south in the next 60 seconds, five in the subsequent minute and over 100 between $18: 30$ and $18: 31$. On 5 October, the crows changed their area of congregation one block south and one block east, over the intersection of University Drive and Clarence Avenue, with 50 circling there a 18:28.

Meanwhile about 7:00, Mar Houston while out jogging would se flocks of 40 to 100 crows leaving thei roost and flying west over the river near the 25th Street bridge.

On 9 October, the Tuesday afte the Thanksgiving holiday weekend the crows were halfway betweer Clarence Avenue and the Universit gates, roosting at the corner 0 University Drive and McKinno Avenue, just a block south of the memorial gates, and one block eas of the 25th Street bridge. Here 
counted 96 crows roosting in five trees, and another 60 circling overhead as I passed at 18:11.

Crows are no longer shot at within the city limits as stragglers undoubtedly were forty years ago. Probably residential areas and the trees on the adjacent University grounds offer a very safe place for their fall congregations. I might have learned much more about them had I not been hurrying home for supper, and $I$ am not at all sure that their raucous cawings are appreciated by the citizens of Saskatoon. Further, small songbirds seem less conspicuous when the crows are out in force.

'HOUSTON, C. S. 1977. Changing patterns of Corvidae on the prairies. Blue Jay 35:149-156.

${ }^{2}$ O'NEIL, P. 1977. Saskatoon Field Notes 23:10.

${ }^{3}$ O'NEIL, P. 1978. Saskatoon Field Notes $27: 11$.

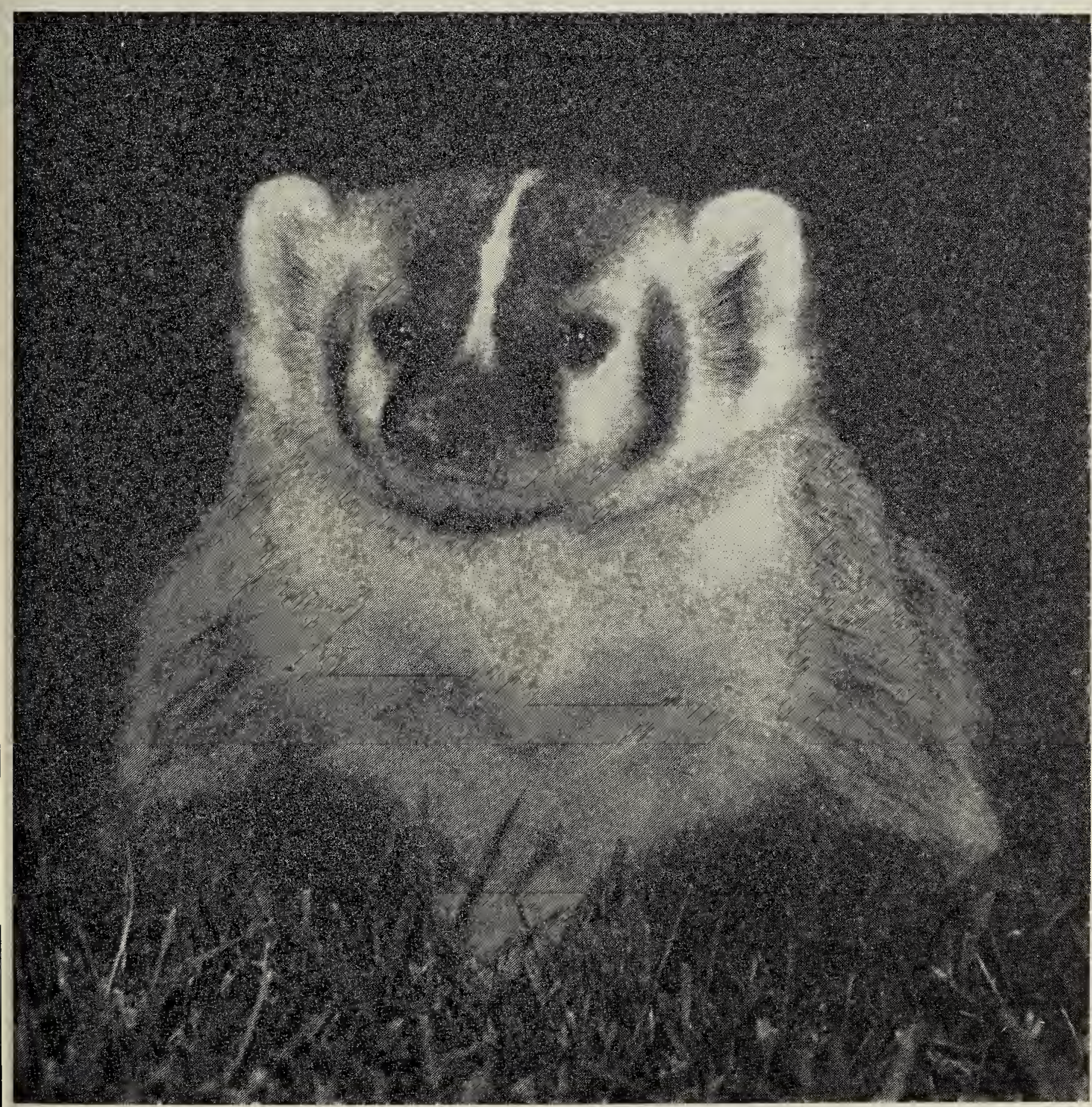

Badger.

Lorne Scott

March, 1980. 38(1) 